\title{
Complicating Digital Nationalism in China
}

\section{Séverine Arsène}

\section{OpenEdition}

\section{Journals}

Electronic version

URL: https://journals.openedition.org/chinaperspectives/10196

DOI: 10.4000/chinaperspectives.10196

ISSN: 1996-4617

Publisher

Centre d'étude français sur la Chine contemporaine

\section{Printed version}

Date of publication: 1 June 2020

Number of pages: 53-57

ISSN: 2070-3449

Electronic reference

Séverine Arsène, "Complicating Digital Nationalism in China", China Perspectives [Online], 2020-2 | 2020, Online since 01 June 2020, connection on 06 July 2021. URL: http://journals.openedition.org/ chinaperspectives/10196; DOI: https://doi.org/10.4000/chinaperspectives.10196

This text was automatically generated on 6 July 2021.

(c) All rights reserved 


\title{
Complicating Digital Nationalism in China
}

\author{
Séverine Arsène
}

SCHNEIDER, Florian. 2018. China's Digital Nationalism. Oxford: Oxford University Press. HAN, Rongbin. 2018. Contesting Cyberspace in China. New York: Columbia University Press. 
1 At the end of April 1999, Chinese hackers hijacked several US government websites. They replaced home pages with messages such as "Protest USA's Nazi action! Protest NATO's brutal action!" In the midst of the war in Kosovo, this was retaliation for the accidental bombing of the Chinese embassy in Belgrade by NATO forces. In July 2006, following a controversy over the handling of anti-
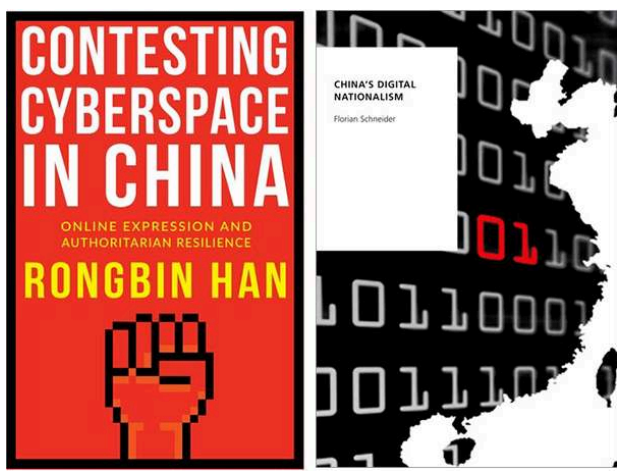
Japan gamers' pseudonyms, users of the online game Fantasy Westward Journey decided to organise a demonstration inside the game, drawing more than 80,000 players onto the same play area and virtually chanting offensive slogans. Anti-Japanese sentiment had been rife since the 2005 protests against Japan's bid to gain a seat in the UN Security Council. The booming Internet ecosystem had played a role in bringing people to the streets, especially forums with a nationalistic undertone such as Strong Nation Forum (Qiangguo luntan 强国论坛).

Ever since the Internet started to develop in China, nationalism has been a prominent feature of the online ecosystem ( $\mathrm{Wu} 2007$ ). These events have long been a theoretical puzzle, as they contradict some of the early optimism about the rise of a democratically oriented civil society online (Yang 2003; Lagerkvist 2005). Indeed they highlight that the Chinese cyberspace is a complicated and contentious space, just like any cyberspace in the world.

3 Two books published respectively by Han Rongbin and Florian Schneider in 2018 bring new empirical and theoretical insights into the question of online nationalism and shed a useful light on the competing ideologies, aspirations, and norms that populate the Chinese Internet. They use very different theoretical and methodological approaches to address this topic. Although nationalism is not directly the focus of Han Rongbin's book Contesting Cyberspace in China, it occupies several chapters and constitutes one of the most interesting and original takeaways of his study.

\section{Overview}

Han Rongbin takes issue with the conceptualisation of the political Internet as one opposing civil society and the state, a Manichean view that dominated much of the scholarship on the topic during the 2000s. Instead, he proposes an entry through "discourse competition." He endeavours to disentangle the institutions and actors that play a role in shaping online discourse.

5 In this, he follows the lead of previous books that have foregrounded the merits of using an interactionist approach to understand the complicated logics through which online discourses are deployed (Yang 2009). While official media have clearly lost their monopoly over the public agenda, and the public sphere hosts more diverse sets of norms than before the Internet (Lagerkvist 2010), scholars have already argued that this is more about liberalisation than about democratisation (Zheng 2008), and that framing logics mean that state-sponsored, nationalist norms are bound to be mainstream online (Arsène 2011). Criticising the "state versus society" paradigm thus 
sounds like a straw man argument. The insistence throughout the book on repelling the illusions of the "resilience" theory means that it remains the reference point of the book, at the risk of failing to open new perspectives on the question. Still, ten years after these publications, Han's book is a welcome update, because much of the landscape has changed, with new institutions, giant corporations, millions more Internet users on their mobile phones, and a much savvier, control-oriented leadership in power. It constitutes a clear, readable, up-to-date reference book on these issues. The book focuses particularly on forums (BBS) and comments. Those platforms have been around for about twenty years now, but they are still vibrant places in terms of public debate. Han draws on 60 online and offline interviews with participants and moderators, as well as online ethnography.

6 Florian Schneider's book China's Digital Nationalism focuses more directly on nationalist content published online. He places the discussion at a more theoretical level, with the ambition to make it a relevant case study beyond China, and to contribute to the literature with insights on what the digital does to nationalism. Indeed, the second chapter is devoted entirely to a theoretical discussion of nationalism, conceptualised here as a "political technology," one that is the result of "a lengthy process of construction, innovation, and negotiation, driven in no small part by elites and their self-interests" (p. 32). The formation of nationalism is mostly a discursive process, whereby emotions, perceptions, and psychology play a great role in people's identity building, so the role of digital communications is decisive.

7 Florian Schneider focuses in particular on two issues that represent two typical facets of Chinese nationalism: the memory of the Nanjing massacre, and debate around the Diaoyu Islands, a hot topic around 2012. Florian Schneider applies both qualitative methods such as content analysis of mainstream websites and platforms and interviews with industry insiders and academics, and quantitative methods such as issue crawling and network visualisation.

Chapters are organised along a series of case studies involving different ways to collect and analyse data. This reads as a journey through all the platforms and filters that shape the information available to Chinese Internet users about the Nanjing massacre and the Diaoyu Islands. The book exemplifies a growing trend of applying digital methods to provide objective, quantified measurements of social phenomena, while also crossing that information with qualitative insights from interviews and content analysis.

Through different materials and methods, both books address the effects of censorship in framing nationalist discourse online, and how this is intricately combined with the political economy of the Internet, platforms' commercial biases, and design choices. They also both study examples of online controversies, where user-generated content offers a glimpse into the psychology, collective identity, and social interactions of nationalist Internet users in China. In other words, both books avoid simplistic and judgmental views of nationalism and provide useful theoretical perspectives to understand it in context.

\section{Structures: The political economy of nationalism}

To be sure, censorship on the Chinese Internet leaves only limited space for discourses that diverge from official positions. Both books address the institutional set up, which 
constrains expression of popular sentiment, including nationalism. They cover some of the main steps in the development of the Great Firewall, which entails technological aspects as well as regulatory and institutional ones. This includes, for example, the Real Name System ( Shi ming zhi 实名制), and reorganisation of the Cyberspace Administration of China.

11 The state outsources control to Internet service providers through the moderation of user-generated content. This puts corporations in a difficult situation where they need to assess what content crosses the line, and arrange sanctions that can range from reducing the visibility of a post to removing it, and to deleting the user's account altogether. In other words, Internet service providers find themselves in an uncomfortable position "between the Party line and the bottom line" (Jiang 2012 based on Zhao 1998). This leads to variations across platforms in terms of what content is censored, and when (MacKinnon 2009).

Han Rongbin (Chapter 3) shows how corporations are constantly walking a fine line, as their profits depend on attracting lively discussion. Some resort to "discontented compliance" (p. 55), with tactics including grumbling, slacking (dragging feet), technical boycotting, managerial activism (lobbying to the authorities), and even "exit and resurrection" (p. 69). How these different tactics play out depends, of course, on the size and affiliation of the corporations, with the largest commercial portals particularly under scrutiny, but also with greater bargaining power.

Hosting nationalist content therefore appears to be an easy way to produce lively (or even inflamed) debate and attract audiences, with little political risk. Florian Schneider addresses this question in the last chapter of his book. He suggests that the "resulting network architecture benefits China's political and commercial elites while at the same time satisfying certain user demands, but it also creates a media ecology that encourages nationalism" (p. 192), although he notes that other kinds of narratives still emerge occasionally.

Beyond the mere application of censorship directives, nationalist discourse is shaped by corporate policies in more mundane ways. For example, in Chapter 3, Schneider compares search engine results from Baidu (百度), Good Search (好搜 by Qihoo 360 奇 虎 360, now known as So 搜), Sogou (搜狗), ChinaSo (中国搜索), and Google. Each of the search results show selection biases, such as censorship and self-promotion. State-run search engine ChinaSo promoted its own affiliated content in $60 \%$ of the queries, whereas all Chinese commercial search engines did so between 30 and $39 \%$ of the time. Because these platforms can only publish state-approved content about issues such as the Nanjing massacre or the Diaoyu Island, self-promotion reduces the diversity of perspectives available. Google was found to promote Google-affiliated content in about $4 \%$ of queries, but it returned materials produced by the Chinese Party-state $18 \%$ of the time, reflecting the organic ways in which information sources emerge as authoritative from the Chinese language online ecosystem. Schneider also shows the impact of "banal biases," such as the automatic display of weather or tourism information concerning the Diaoyu Islands, although they are in fact inaccessible to anyone.

\section{Old and new features of propaganda}

The framing of online nationalism also happens through the state-sponsored publication of content. Schneider collected the 19 most visible websites (according to 
search results) dedicated to the Nanjing Massacre and to the Diaoyu Islands and concluded that these websites reflect publication patterns directly imported from traditional media. First, contrary to expectations, they are "not tied into anything that can be called an issue network" (Chapter 4, p. 95). In other words, they do not link to each other. Instead, they seem to maintain a traditional mass-media logic with very little interactivity or links to sources of information, which goes against the culture of "see for yourself" that characterises the web.

16 In terms of content (Chapter 5), these mostly institutional websites tend to display a one-way communication pattern that is not conducive to exchange or critical examination of data. Sites dedicated to the Nanjing Massacre, such as the Nanjing Massacre Memorial Hall website (Qin Hua Rijun Nanjing da tusha yunan tongbao jinianguan 侵华日军南京大屠杀遇难同胞纪念馆) and the Never Forget (Yong bu wangque 永不忘 却) commemoration site on Sina.com, tend to perform the function of a shrine, with prominent use of emotional vocabulary and visuals. Websites dedicated to the Diaoyu Islands (Chapter 6) put forward a strategy of "measuring, counting, and naming" (p. 138), as a performative action that constructs sovereignty.

17 This logic also underlies the fabrication of content about the Nanjing Massacre in participative encyclopaedias such as Baidu Baike 百度百科 or Hudong 互動百科 (Chapter 5). All China-based encyclopaedias have an additional editorial layer conducted by employees of the platform, unlike Wikipedia, which is entirely written and edited by volunteer users (Liao 2015). Compared to China-hosted services, Chinese Wikipedia has the longest and most referenced entry on the Nanjing Massacre. It is a patchwork of contributions with scholarly and casual discourses partly contradicting each other, but that precisely puts the emphasis on the need to take into account different perspectives. By way of contrast, the Chinese encyclopaedias present a much simpler, edited, and apparently uncontroversial version of events, with little attention to sources or editorial ethics (Baidu and Hudong replicate Wikipedia and each other).

Schneider also highlights that such a hot topic as the Diaoyu Islands generated a diversity of websites, including some run by (pro-China) volunteer groups, and by various pro-Beijing organisations in Hong Kong, for example. The Diaoyu Islands are also a prominent topic on commercial military sites. These websites tend to reuse official discourse but also re-appropriate that content in unorthodox ways, and incorporate less tidy features. For example, some of them display very misogynistic characteristics, both in the language used and in the suggestive advertisements displayed. Florian Schneider's hypothesis is that commercial dynamics constitute an encouragement to construct the issue in a nationalistic and misogynistic way, which is most likely to attract specific audiences. In other words, nationalism has been "commodified" (Chapter 6, p. 159).

19 Florian Schneider's extensive examination shows the clear weaknesses of statesponsored and state-approved commercial content. Stuck in twentieth-century forms of publication, ignoring web-native referencing and linking practices, and with built-in incentives to favour misogynistic, aggressive, emotional types of expression, they lack credibility and appeal. Because of the extent of censorship and bias in online information gatekeepers, they still occupy a dominant position online, and one has to dig into search results and sub-threads of comments in order to find expressions of more diversity. 
However, his choice of fieldwork does not allow Schneider to account sufficiently for the new strategies devised by propaganda departments to modernise their communication and strike a chord with younger generations.

First, it appeared quite early that the state was paying commentators to engage in astroturfing, a classic public relations strategy that consists in flooding online platforms with positive comments, under the pretence of being regular users (Bandurski 2008). Their posts are highly recognisable, as they tend to use identical phrases, and they often get chastised online for upholding the government's propaganda.

Han Rongbin's Chapter 5 digs deeper and unearths propaganda directives and official websites that explain the strategy candidly. State-sponsored trolls were firstly local initiatives, then spread all around the country, and they are now supplemented by national organisations such as the Communist Youth League. The latter can recruit large numbers of commentators nationally, notably in universities. They are mobilised in waves at times of crisis, or to help spread and clarify state policies.

Han Rongbin shows that the low level of remuneration and training indicates low expectations. Posters rarely engage in substantial exchanges with other Internet users and simply repeat typical elements of language that no one takes seriously anymore. This is counterproductive. However, as other scholars have pointed out, the main goal may simply be to distract or repel readers, not to convince them (King, Pan, and Roberts 2016). In fact, despite the apparent clumsiness of the strategy, elements of language from Chinese propaganda do travel around the global Internet (Roberts 2018, Chapter 6). Beyond astroturfing, Chinese propaganda has developed a range of more sophisticated strategies.

24 Over the years, the Chinese propaganda apparatus recognised the importance of communicating in ways that appeal to the younger generation online. Indeed Han Rongbin's Chapter 4 shows how popular culture has become a vector of activism, in playful ways that are not easily classified as political or apolitical, and thus escape censorship easier.

Recognising this, the Communist Youth League (Gongchanzhuyi Qingnian Tuan 共产主义 青年团) and major news organisations such as People's Daily (Renmin ribao 人民日报) have been instrumental in devising ways to leverage popular culture and entertainment for nationalistic purposes. For instance, the gaming industry has been co-opted to produce games featuring historical events such as the "War of Resistance against Japan," with mixed results (Nie 2013). More recently, the turn to a cult of personality for president Xi Jinping also involved the production of popular cultural content, such as songs, cartoons, and anime (Chang and Ren 2018). But concurrently, Internet users produced satirical content, including a meme comparing Xi to Winnie the Pooh, which was eventually deleted from some platforms.

Other case studies show how propaganda departments and official media organisations have turned to Weibo to display a more empathetic discourse and create a sense of community (Li 2015).

The sarcastic and at times aggressive reactions of Chinese audiences to nationalistic content promoted by the state already complicate the understanding of the origins of online nationalism in China, as it becomes difficult to just assume that Chinese Internet users are manipulated by propaganda. However, the emergence of clear evidence of 
voluntary, non-state sponsored online nationalism is bringing even more complexity into this picture.

\section{Collective identity and popular culture} despite the violence of some calls to action. They can serve as a lever in Chinese diplomacy, as the authorities could argue that they had to respond to popular sentiment (Wu 2007). On the other side, the authorities have regularly had to step in 
with increased censorship to protect diplomatic relationships and keep public order under control.

This complicated relationship, as Florian Schneider shows in Chapter 7, is often one of negotiated meanings. He studies posts by some of the most influential opinion leaders on Weibo during the Diaoyu Islands crisis and notes that many of them navigated the crisis either by limiting their posts on the topic to mere retweets or insignificant posts, or by using ambiguous, somewhat ironic language.

Schneider shows that the configuration of the platform matters. More or less visibility, the intended purpose of the forum, and the kind of people who populate it all contribute to shaping what is perceived as accepted discourse (also see Arsène 2011, Chapter 6). Paradoxically, the advent of WeChat (Weixin 微信), a more private instant messaging platform launched in 2011, does not necessarily make this negotiation any easier, as users interact with family, friends, or colleagues, people they know and with whom they need to respect particular norms of interaction. "Familiar friend circles indeed promotes discourse that is responsible, civilized, and in good taste" (p. 192). Besides, we also know that the platform censors content very heavily, including private chats ( $\mathrm{Ng}$ et al. 2016). Arguably, one could add that timing counts as well. Under times of crisis, the lines tend to move in unpredictable ways, as the coronavirus crisis is showing, with Internet users dropping all sense of patriotism to criticise the regime's handling of the crisis, while propaganda organs are engaged in a disinformation battle to contest the Chinese origins of the virus. ${ }^{1}$

\section{Brutalisation of public debate}

Through different fieldworks and methods, both authors come to the same conclusion. The pervasive censorship, manipulation, and polarisation of public space that is occurring in the Chinese cyberspace means that the entire public sphere suffers from a lack of credibility and is hostile to any constructive debate, something akin to the "brutalisation of public debate" conceptualised by Badouard (2018).

Han Rongbin shows how a logic of "us versus them" prevails in the labelling wars between 50-centers and pro-democracy activists (“50-cent” 五毛 versus "pussies” 普世 for pushi, universalism). As he concludes, "online expression has done more to delegitimize the regime than to spread civic and democratic norms" (p. 190).

Florian Schneider also concludes with the destruction of democratic values online. Based on Mumford (1964), he argues that the Chinese Internet is marked by paternalistic, centralising technics of government, and more importantly that those technics are not exclusively features of an authoritarian regime. In other terms, this pattern is visible whenever nationalism thrives online. This is the strong message underlying both books. Although these case studies were conducted in China, they convey important implications for the rest of the world, including in democratic regimes. It is one thing to fight against censorship, propaganda, fake news, and manipulation. Another challenge altogether is how to build the conditions for an inclusive, peaceful, and constructive public space.

LIU, Hailong (ed.). 2019. From Cyber-Nationalism to Fandom Nationalism : The Case of Diba Expedition In China. London: Routledge. 


\section{BIBLIOGRAPHY}

ARSÈNE, Séverine. 2011. Internet et politique en Chine (Internet and Politics in China). Paris: Karthala.

BADOUARD, Romain. 2018. "Internet et la brutalisation du débat public" (Internet and the Brutalisation of Public Debate). La Vie des idées November. http://www.laviedesidees.fr/Internetet-la-brutalisation-du-debat-public.html (accessed on 21 March 2020).

BANDURSKI, David. 2008. “China's Guerrilla War for the Web.” Far Eastern Economic Review July: 41-4.

CHANG, Jiang, and Hailong REN. 2018. "The Powerful Image and the Imagination of Power: The 'New Visual Turn' of the CPC's Propaganda Strategy since its $18^{\text {th }}$ National Congress in 2012." Asian Journal of Communication 28(1): 1-19.

HUANG, Zhao Alexandre, and Rui WANG. 2019. "Building a Network to 'Tell China Stories Well': Chinese Diplomatic Communication Strategies on Twitter." International Journal of Communication 13: 24 .

JIANG, Min. 2012. "Internet Companies in China: Dancing between the Party Line and the Bottom Line.” Asie Visions. Paris: IFRI. https://www.ifri.org/en/publications/enotes/asie-visions/ internet-companies-china-dancing-between-party-line-and-bottom-line (accessed on 20 March 2020).

KING, Gary, Jennifer PAN, and Margaret E. ROBERTS. 2017. "How the Chinese Government Fabricates Social Media Posts for Strategic Distraction, Not Engaged Argument." American Political Science Review 111(3): 484-501.

LAGERKVIST, Johan. 2005. "The Rise of Online Public Opinion in the People's Republic of China." China: An International Journal 3(1): 119-30.

LAGERKVIST, Johan. 2010. After the Internet, Before Democracy: Competing Norms in Chinese Media and Society. Berlin: Peter Lang.

LI, Angela Ke. 2015. "Towards a More Proactive Method: Regulating Public Opinion on Chinese Microblogs under Xi's New Leadership." China Perspectives 4(104): 15-23.

LIAO, Han-Teng. 2015. "Harnessing the Power of Collaborative Filtering. Comparing the Network Gatekeeping of Baidu Baike and Chinese Wikipedia." China Perspectives 4(104): 35-49.

LIU, Shih-Diing. 2006. "China's Popular Nationalism on the Internet. Report on the 2005 AntiJapan Network Struggles." Inter-Asia Cultural Studies 7(1): 144-55.

MACKINNON, Rebecca. 2009. “China's Censorship 2.0: How Companies Censor Bloggers.” First Monday 14(2). http://firstmonday.org/article/view/2378/2089 (accessed on 20 March 2020).

MUMFORD, Lewis. 1964. “Authoritarian and Democratic Technics.” Technology and Culture 5(1): $1-8$.

NG, Jason Q, Jeffrey KNOCKEL, Lotus RUAN, and Masashi CRETE-NISHIHATA. 2016. “One App, Two Systems: How WeChat Uses One Censorship Policy in China and Another Internationally." The Citizen Lab, 30 November. https://citizenlab.ca/2016/11/wechat-china-censorship-one-app-twosystems (accessed on 21 March 2020). 
NIE, Hongping Annie. 2013. “Gaming, Nationalism, and Ideological Work in Contemporary China: Online Games Based on the War of Resistance against Japan." Journal of Contemporary China 22(81): 499-517.

ROBERTS, Margaret E. 2018. Censored: Distraction and Diversion Inside China's Great Firewall. Princeton: Princeton University Press.

WU, Xu. 2007. Chinese Cyber Nationalism : Evolution, Characteristics, and Implications. Lanham: Lexington Books.

YANG, Guobin. 2003. "The Co-Evolution of the Internet and Civil Society in China." Asian Survey 43(3): 405-22.

YANG, Guobin. 2009. The Power of the Internet in China : Citizen Activism Online. New York: Columbia University Press.

ZHANG, Yinxian, Jiajun LIU, and Ji-Rong WEN. 2018. "Nationalism on Weibo: Towards a Multifaceted Understanding of Chinese Nationalism.” The China Quarterly 235: 758-83.

ZHAO, Yuezhi. 1998. Media, Market, and Democracy in China: Between the Party Line and the Bottom Line. Urbana: University of Illinois Press.

ZHENG, Yongnian. 2008. Technological Empowerment: The Internet, State, and Society in China. Stanford: Stanford University Press.

\section{NOTES}

1. Li yuan, "Coronavirus Weakens China's Powerful Propaganda Machine," The New York Times, 26 February 2020, https://www.nytimes.com/2020/02/26/business/chinacoronavirus-propaganda.html (accessed on 15 April 2020).

\section{INDEX}

Keywords: China, digital, internet, social media, nationalism, 50-cent, propaganda. 